\title{
Prevalence and Treatment of Tobacco Use among Patients Being Treated for Mental Disorders
}

\author{
Prevalencia y Tratamiento del Uso de Tabaco \\ Entre Pacientes de Servicios de Salud Mental
}

\author{
Prevalência e Tratamento do Uso de Tabaco \\ Entre Pacientes Tratados em Serviços de Saúde
} Mental

Telmo Mota Ronzani

ORCID ID: 0000-0002-8927-5793

Universidade Federal de Juiz de Fora, Brasil

Bárbara Any Bianchi Bottaro de Andrade

ORCID ID: 0000-0002-2745-5406 Universidade Federal de Juiz de Fora, Brasil

Henrique Pinto Gomide ORCID ID: 0000-0001-7050-3971 Universidade Federal de Viçosa, Brasil

Fernando Antonio Basile Colugnati ORCID ID: 0000-0002-8288-203 Universidade Federal de Juiz de Fora, Brasil

Autor referente: tm.ronzani@gmail.com

Historia editorial Recibido: 12/09/2018 Aceptado: 04/02/2020

\footnotetext{
ABSTRACT

Background: People with mental disorders use tobacco as a strategy for coping with various symptoms and the side effects of prescribed medications. In addition to being harmful to their health, tobacco use also interferes with
}

their treatment process. Objective: To examine tobacco use among patients being treated for mental disorders in a public health system in a Brazilian the city. Methods: were interviewed 362 patients being treated by the 
specialized services for mental health. The participants included persons who met the diagnostic criteria for schizophrenia, schizotypal, and delusional disorders, mood (affective) disorders, or neurotic, stress-related, and somatoform disorders. Results: The median age of participants was 46.4 years, of which $73.5 \%$ were women and $42.5 \%$ were unmarried, $37.8 \%$ smokers. Among the smokers, $82 \%$ claimed they wanted to quit smoking, and $49 \%$ made daily visits to the health center. $79.6 \%$ of the participants had tried to quit smoking previously, and of these, $84.3 \%$ had tried to do so on their own. Conclusion: Tobacco use is an important factor to be considered in developing treatment plans for people with mental disorders. It is necessary to develop strategies to help people quit smoking and train health professionals to incorporate these strategies into the treatment process.

Keywords: Smoking; mental health; co-occuring disorders; tobacco dependence

\section{RESUMEN}

Antecedentes: Personas con trastornos mentales utilizan el tabaco como estrategia de afrontamiento para diversos síntomas y efectos colaterales de los medicamentos utilizados. Además de los múltiples daños causados a la salud, el uso de tabaco perjudica el tratamiento de personas con trastornos mentales. Objetivo: Caracterizar el consumo de tabaco en la población con trastorno mental en tratamiento, en la ciudad de Juiz de Fora, Brasil. Métodos: Fueron entrevistados 362 pacientes en tratamiento, en los servicios especializados en salud mental, con diagnósticos de Esquizofrenia, Trastornos Esquizotípicos y Delirantes, Trastornos del Humor (afectivos) o Trastornos Neuróticos, Trastornos Relacionado con Estrés y Trastornos
Somatomorfos. Resultados: La edad promedio de los participantes fue de 46,4 años; el $73,5 \%$ eran del sexo femenino, el $42,5 \%$ eran solteros y un $37,8 \%$ eran fumadores. El $82 \%$ afirmó que les gustaría dejar de fumar y el $49 \%$ frecuentaron el servicio diariamente. Aquellos que ya intentaron parar de fumar alguna vez totalizaron el $79,6 \%$ y, de los cuales el $84,3 \%$ lo hicieron por cuenta propia. Conclusión: El consumo de tabaco es un factor importante a ser considerado en la elaboración de procedimientos terapéuticos de la población con trastornos mentales. Es necesario desarrollar intervenciones para el cese del consumo de tabaco, que puedan ser aplicados en la cotidianidad de los servicios de forma integrada.

Palabras-claves: Tabaquismo; salud mental; comorbilidad; uso de tabaco

\section{RESUMO}

Antecedentes: Pessoas com transtornos mentais utilizam o tabaco como estratégia de enfrentamento para diversos sintomas e efeitos colaterais dos medicamentos utilizados. Além dos diversos prejuízos à saúde, o uso de tabaco prejudica o tratamento de pessoas com transtornos mentais. 
Objetivo: caracterizar o consumo de tabaco na população portadora de transtorno mental em tratamento na cidade de Juiz de Fora, Minas Gerais. Métodos: Foram entrevistados 362 pacientes em tratamento nos serviços especializados em saúde mental, com diagnósticos para Esquizofrenia, Transtornos Esquizotípicos e Delirantes, Transtornos do Humor (afetivos), ou Transtornos Neuróticos, Transtornos Relacionados ao Stress e Transtornos Somatoformes. Resultados: A idade média dos participantes foi de 46,4 anos; $73,5 \%$ eram do sexo feminino e $42,5 \%$ solteiros e $37,8 \%$ eram fumantes. $82 \%$ alegaram que gostariam de parar de fumar e $49 \%$ frequentavam o serviço diariamente. Aqueles que já tentaram parar de fumar alguma vez totalizaram $79,6 \%$ e, desses, $84,3 \%$ o fizeram por conta própria. Conclusão: O consumo de tabaco é um fator importante a ser considerado na elaboração do plano terapêutico da população com transtornos mentais. É necessário desenvolver intervenções para a cessação do consumo de tabaco que possam ser aplicadas no cotidiano dos serviços de forma integrada.

Palavras-chave: Tabagismo; saúde mental; comorbidades; uso de tabaco

Ithough tobacco use continues to be the world's number one preventable cause
of disease and death (Johnson et al ., 2010; World Health Organization, 2011; World Health Organization, 2019), tobacco is one of the most frequently used psychoactive substances (Degenhardt \& Hall, 2001; Thornton, Baker, Johnson \& Lewin, 2013; Ziedonis et al., 2008). According to some studies (Degenhardt \& Hall, 2001; Teesson, Slade \& Mills, 2009; Thornton et al., 2012), the use of tobacco, alcohol, and cannabis is more common among people with mental disorders, even though these substances can interfere with their treatment.

In addition to the health risks it poses, smoking also reduces the efficacy of medications for mental disorders, exacerbates their psychiatric symptoms, increases the chances of relapse, hospitalization, or victimization (Degenhardt \& Hall, 2001; Thornton et al., 2012). People with mental disorders have a higher mortality rate from smoking-related diseases, such as cardiovascular, respiratory diseases, and cancer. Due to the various repercussions of smoking, research indicates that smokers should be closely observed for changes in their clinical conditions (Johnson et al., 2010). 
People with mental disorders are among the groups that are most susceptible to tobacco use and smoking (Johnson et al., 2010; Scherer, Scherer, Azevedo, \& Durão, 2012). The course and treatment of these disorders are negatively affected by tobacco use (Mackowick, Lynch, Weinberger, \& George, 2012; Thornton et al., 2013,), making it an even more serious problem for these patients' health (Degenhardt \& Hall, 2001; Thornton et al., 2012). The literature indicates higher rates of tobacco use (Johnson et al., 2010) and lower rates of quitting among this population, compared to the general population (Mackowick et al., 2012). Then, cessation support systems are more effective if they include an evaluation and intervention that take into account the mental health status (World Health Organization, 2019).

Research indicates that the most frequent reason for tobacco use cited by patients with mental disorders is that it offers a way of coping with psychiatric symptoms and the side effects of prescribed medications (Degenhardt \& Hall, 2001; Scherer et al., 2012; Thornton et al., 2012). Therefore, tobacco is employed as a coping strategy and can take on an important role in the lives of patients with mental disorders (Scherer et al., 2012).

Although considered co-occurring disorders, psychiatric treatment and treatment for tobacco use are rarely integrated even though literature shows that treatment for mental disorders and substance abuse are more effective when treated jointly in a single clinical program rather than separately (Thornton et al., 2012). Scherer et al. (2012) indicate that the failure to integrate tobacco quitting strategies into the routine of mental health services interferes with the treatment for controlling tobacco use for these patients.

This study aims to estimate the prevalence of tobacco use among patients with mental disorders. It also describes the patients' characteristics like mental health diagnosis, tobacco history (i.e., prior treatment and number of quit attempts) and types of 
treatment for quitting tobacco offered by the mental health service of the city of Juiz de Fora, in the state of Minas Gerais, Brazil.

\section{Methods}

\section{Study Design and Subjects}

This is a descriptive study of a cross-section, convenience sample of patients receiving treatment from the specialized mental health services associated with the Municipal Department of Health of the city of Juiz de Fora, Brazil. The city is a medium-sized city of approximately 600,000 inhabitants in the southeast of Brazil.

To be included in the study, patients had to: (a) meet the criteria set out the in the 10th edition of the International Classification of Diseases (ICD-10) for schizophrenia, schizotypal, and delusional disorders (SSDD, F20-F29), mood (affective) disorders (F30-F39) or neurotic, stress-related, and somatoform disorders (NSSD, F40-F-48); (b) be receiving treatment from the municipal services specialized in mental disorders; and (c) be older than 18 years. In this study patients receiving two modes of treatment were included: (a) those who came in for periodic appointments and (b) those who were treated on a daily basis.

\section{Measurements}

Sociodemographic data was gathered using a questionnaire that asked about the patients' age, gender, marital status, profession, family income, level of education, religious denomination, locations where treatment was received in the past, the number of times treatment was sought for a mental disorder, and the duration of hospitalizations.

Data about tobacco use was obtained using a questionnaire developed by the research team based on the PETab (Instituto Nacional do Câncer, 2011) that asked about how 
many years the patient had used tobacco regularly, the age at which tobacco had first been used, daily consumption (in number of cigarettes), the type of tobacco product used (manufactured or hand-rolled cigarettes, snuff, and other tobacco products), whether any attempt had been made to quit, how that this had been attempted, and the user's motivation for quitting.

\section{Procedures}

Our study was authorized by the manager of the Municipal Department of Mental Health and the coordinators of the services that were visited. We consulted the patients' medical records to identify their most recent diagnoses and approached the patients who met the project's criteria at the facility where they were being treated. Patients receiving daily care were approached at a convenient time that did not interfere with their treatment, and those who came in for periodic appointments were approached while they were waiting for their session to begin.

Participants were assured that their identities and any information they provided would remain anonymous and confidential. Personal interviews were conducted to avoid causing the participant any discomfort, and participants were free to withdraw from the study at any time.

\section{Statistical Analysis}

The data collected was entered separately by two researchers (or trained research assistants) into a database, using version 15.0 of the Statistical Package for Social Sciences (SPSS). Data entry errors detected on comparison of the two data entered by the two researchers were corrected. The variables were subjected to descriptive statistical analysis of the sample (mean, median, standard deviation, interquartile range, and frequency of the ordinal and nominal variables). 


\section{Ethical Considerations}

Participants were informed of the purpose, procedures, and ethical considerations of the research project by means of a reading and explanation of the Free and Informed Consent form. The project was deemed to present minimal risk, according to CNS resolution 196/96, and was approved by the Research Ethics Committee of the Federal University of Juiz de Fora (UFJF) in finding no. 007/2011.

\section{Results}

Of the 362 patients interviewed, $42.5 \%(n=154)$ were treated at the Mental Health Treatment Center, 46.7\% $(n=165)$ were treated at the Psychosocial Treatment Center (CAPS, in its Portuguese acronym), and $10.8 \%$ were treated at the non-residential care centers or lived at one of the three city residential treatment centers. The mean age for patients was 46.4 years ( $S D=10.3$ years), $73.5 \%$ were female and $42.5 \%$ were unmarried. Demographics and clinical characteristics of the sample are shown in Table 1. 
Table 1

Description of participants demographics $(N=362)$

\begin{tabular}{|c|c|c|c|c|}
\hline \multirow{2}{*}{ Characteristics } & Participants & Smokers & $\begin{array}{l}\text { Non- } \\
\text { Smokers }\end{array}$ & $p$-value \\
\hline & $\%(n)$ & $\%(n)$ & $\%(n)$ & Chi-square \\
\hline $\begin{array}{l}\text { Age in years } \\
\text { (mean and SD) }\end{array}$ & $\begin{array}{c}46.4 \\
(10.32)^{*}\end{array}$ & $\begin{array}{c}48.7 \\
(8.87)^{*}\end{array}$ & $44.9(10.9)^{*}$ & $0.001^{\#}$ \\
\hline Gender & & & & 0.368 \\
\hline Female & $\begin{array}{l}73.5 \% \\
(266)\end{array}$ & $\begin{array}{c}36.5 \% \\
(97)\end{array}$ & $63.5 \%(196)$ & \\
\hline Male & $26.5 \%(96)$ & $\begin{array}{c}41.7 \% \\
(40)\end{array}$ & $58.3 \%(56)$ & \\
\hline Marital status & & & & 0.023 \\
\hline Single & $\begin{array}{l}42.5 \% \\
(154)\end{array}$ & $\begin{array}{c}48.9 \% \\
(67)\end{array}$ & $38.7 \%(87)$ & \\
\hline $\begin{array}{l}\text { Married/Lives with } \\
\text { partner }\end{array}$ & $\begin{array}{l}36.5 \% \\
(132)\end{array}$ & $\begin{array}{c}27.0 \% \\
(37)\end{array}$ & $42.2 \%(95)$ & \\
\hline Divorced & $15.2 \%(55)$ & $\begin{array}{c}16.1 \% \\
(22)\end{array}$ & $14.7 \%(33)$ & \\
\hline Educational level & & & & 0.112 \\
\hline $\begin{array}{l}\text { High school } \\
\text { graduate }\end{array}$ & $\begin{array}{l}33.1 \% \\
(120)\end{array}$ & $\begin{array}{c}25.5 \% \\
(35)\end{array}$ & $37.8 \%(85)$ & \\
\hline $\begin{array}{l}\text { Secondary } \\
\text { education complete }\end{array}$ & $\begin{array}{l}27.9 \% \\
(113)\end{array}$ & $\begin{array}{c}34.4 \% \\
(47)\end{array}$ & $29.3 \%(66)$ & \\
\hline $\begin{array}{l}\text { Primary education } \\
\text { complete }\end{array}$ & $\begin{array}{l}31.2 \% \\
(101)\end{array}$ & $\begin{array}{c}33.6 \% \\
(46)\end{array}$ & $24.4 \%(55)$ & \\
\hline $\begin{array}{l}\text { Number of years } \\
\text { in school }\end{array}$ & $8.8(3.91)^{*}$ & $7.9(3.79)^{*}$ & $21.5(96.2)^{*}$ & $0.001^{\#}$ \\
\hline $\begin{array}{l}\text { Are you currently } \\
\text { employed? }\end{array}$ & & & & 0.070 \\
\hline No (unemployed) & $\begin{array}{c}18.4 \% \\
(100)\end{array}$ & $\begin{array}{c}23.9 \% \\
(32)\end{array}$ & $31.2 \%(68)$ & \\
\hline
\end{tabular}


Table 1 Description of participants demographics ( $N=362)$ (Continuation)

\begin{tabular}{|c|c|c|c|c|}
\hline Characteristics & Participants & Smokers & $\begin{array}{c}\text { Non- } \\
\text { Smokers }\end{array}$ & $p$-value \\
\hline & $\%(n)$ & $\%(n)$ & $\%(n)$ & Chi-square \\
\hline Yes (employed) & $15.2 \%(74)$ & $\begin{array}{c}12.7 \% \\
(17)\end{array}$ & $17.9 \%(39)$ & \\
\hline Retired/Disability & $\begin{array}{l}55.7 \% \\
(196)\end{array}$ & $\begin{array}{c}63.4 \% \\
(85)\end{array}$ & $50.9 \%(111)$ & \\
\hline Family income & & & & 0.398 \\
\hline $\begin{array}{l}1-3 \times \text { minimum } \\
\text { wage }\end{array}$ & $\begin{array}{l}49.6 \% \\
(178)\end{array}$ & $\begin{array}{c}48.9 \% \\
(67)\end{array}$ & $50.0 \%(111)$ & \\
\hline $\begin{array}{l}\text { Up to } 1 \text { minimum } \\
\text { wage }\end{array}$ & $20.6 \%(74)$ & $\begin{array}{c}24.1 \% \\
(33)\end{array}$ & $18.5(41)$ & \\
\hline Did not respond & $16.7 \%(60)$ & $15.3 \%(21)$ & $17.6 \%(39)$ & \\
\hline
\end{tabular}

Tobacco was used by $37.8 \%(n=137)$ of those interviewed $(41.7 \%$ men and $36.5 \%$ women). The sample size provides a $95 \%$ level of confidence for sample error of 5 percent points. The confidence interval for this estimate is therefore $32.8 \%-42.8 \%$. Also, the sample provides $80 \%$ power for associations measured by prevalence ratios of approximately 2.5 .

A majority of the smokers $(63.7 \%)$ declared that they had been hospitalized in a psychiatric facility for treatment of their mental disorder, while $46.1 \%$ of the nonsmokers had been hospitalized $(p<0.001)$. It was noted that non-smokers reported higher levels of education and there was a 12.3 percentage point difference between the high-school graduation rates of smokers (25.5\%) and non-smokers $(37.8 \%)$ $(p=0.112)$. The mean number of years of schooling reported by smokers was 7.9 years, while for non-smokers it was 21.5 years $(p<0.001)$. 
Of the 137 patients who used tobacco, 48.2\% had been diagnosed with mood (affective) disorders, 29.2\% with schizophrenia, schizotypal, and delusional disorders (SSDD), and $21.9 \%$ with some form of neurotic, stress-related, or somatoform disorder (NSSD), according to the ICD-10. When classified according to the mode of treatment, tobacco was used by $33.5 \%$ of those who come in for periodic appointments with healthcare staff and by $49 \%$ of those who received daily care. More details can be seen at table 2.

Table 2

Mental health related characteristics of the participants $(N=362)$.

\begin{tabular}{|c|c|c|c|c|}
\hline \multirow{2}{*}{ Characteristics } & Participants & Smokers & $\begin{array}{c}\text { Non- } \\
\text { Smokers }\end{array}$ & $p$-value \\
\hline & $\%(n)$ & $\%(n)$ & $\%(n)$ & $\begin{array}{l}\text { Chi- } \\
\text { square }\end{array}$ \\
\hline $\begin{array}{l}\text { How long have you } \\
\text { been receiving } \\
\text { treatment? }\end{array}$ & & & & 0.749 \\
\hline $\begin{array}{l}\text { More than } 11 \\
\text { years }\end{array}$ & $\begin{array}{l}34.5 \% \\
(124)\end{array}$ & $\begin{array}{l}35.6 \% \\
(48)\end{array}$ & $33.9 \%(76)$ & \\
\hline 7 to 10 years & $24.2 \%(87)$ & $\begin{array}{c}24.4 \% \\
(33)\end{array}$ & $24.1 \%(54)$ & \\
\hline 4 to 6 years & $15.3 \%(55)$ & $\begin{array}{c}17.0 \% \\
(23)\end{array}$ & $14.3 \%(32)$ & \\
\hline 1 to 3 years & $14.2 \%(51)$ & $\begin{array}{c}11.1 \% \\
(15)\end{array}$ & $16.1 \%(36)$ & \\
\hline Up to 1 year & $7.5 \%(27)$ & $6.7 \%(9)$ & $8.0 \%(18)$ & \\
\hline Did not respond & $4.2 \%(15)$ & $5.2 \%(7)$ & $3.6 \%(8)$ & \\
\hline $\begin{array}{l}\text { Have you been } \\
\text { hospitalized for a } \\
\text { mental disorder? }\end{array}$ & & & & 0.001 \\
\hline Yes & $\begin{array}{l}52.8 \% \\
(187)\end{array}$ & $\begin{array}{c}63.7 \% \\
(86)\end{array}$ & $46,1 \%(101)$ & \\
\hline
\end{tabular}


Table 2. Mental health related characteristics of the participants ( $N=362)$ (Continuation)

\begin{tabular}{|c|c|c|c|c|}
\hline Chorontoriotion & Participants & Smokers & $\begin{array}{l}\text { Non- } \\
\text { Smokers }\end{array}$ & $p$-value \\
\hline & $\%(n)$ & $\%(n)$ & $\%(n)$ & $\begin{array}{l}\text { Chi- } \\
\text { square }\end{array}$ \\
\hline No & $\begin{array}{c}47.2 \% \\
(167)\end{array}$ & $36.3 \%(49)$ & $53.9 \%(118)$ & \\
\hline Type of disorder & & & & 0.131 \\
\hline $\begin{array}{l}\text { Mood (affective) } \\
\text { disorders }\end{array}$ & $\begin{array}{l}46.1 \% \\
(167)\end{array}$ & $48.2 \%(66)$ & $44.9 \%(101)$ & \\
\hline $\begin{array}{l}\text { Neurotic, stress- } \\
\text { related and } \\
\text { somatoform } \\
\text { disorders. }\end{array}$ & $\begin{array}{c}27.9 \% \\
(101)\end{array}$ & $21.9 \%(30)$ & $31.6 \%(71)$ & \\
\hline $\begin{array}{l}\text { Schizophrenic, } \\
\text { schizotypal and } \\
\text { delusional disorders. }\end{array}$ & $24.6 \%(89)$ & $29.2 \%(40)$ & $21.8 \%(49)$ & \\
\hline Treatment mode & & & & 0.007 \\
\hline Out-patient & $\begin{array}{l}72.9 \% \\
(263)\end{array}$ & $64.7 \%(88)$ & $77.8 \%(175)$ & \\
\hline Intensive & $27.1 \%(98)$ & $35.3 \%(48)$ & $22.2 \%(50)$ & \\
\hline
\end{tabular}

Based on the data shown in Table 3, interviewees reported having smoked regularly for 31.5 years (median value, with an interquartile distance of 23.7). The most commonly used form of tobacco was manufactured cigarettes, though $13.1 \%$ reported using handrolled cigarettes and $5.8 \%$ used tobacco in other forms.

When they were asked if they wanted to quit, $82.5 \%$ of the patients reported in the affirmative. In addition, $79.6 \%$ of the patients reported previous attempts to quit smoking, but only $15.7 \%$ had received any type of treatment to help them quit. 
Table 3

Tobacco measures of participants who smoked $(N=137)$.

\begin{tabular}{ll}
\hline Characteristics & Mean (SD), \% (N)
\end{tabular}

How long have you smoked regularly (years)?

$31.5(23.75)^{\star}$

Age at which you began smoking

$19.9(10.44)$

Number of cigarettes smoked per day, on average

Less than 10

$35.8 \%(49)$

11 to 20

$48.2 \%(66)$

More than 20

$14.6 \%(20)$

Did not respond

$1.5 \%(2)$

Tobacco product used

Manufactured cigarettes

$93.4 \%(128)$

Hand-rolled cigarettes

$13.1(18)$

Others

$5.8 \%(8)$

Would you like to quit smoking?

Yes

$82.5 \%(113)$

No

$17.5 \%(24)$

Have you ever tried to quit smoking?

Yes

$79.6 \%(109)$

No

$19.9 \%(27)$

Did not know

$0.7 \%(1)$

Most recent attempt to quit smoking

More than 12 months ago

$45.8 \%(49)$

Last month

$20.6 \%(22)$

Up to 6 months ago $16.8 \%(18)$

(Continue) 
Table 3 Tobacco measures of participants who smoked ( $\mathrm{N}=137)$. (Continuation)

\begin{tabular}{ll}
\hline Characteristics & Mean (SD), \% (N) \\
\hline Up to 12 months ago & $14.0 \%(15)$ \\
Did not respond & $2.8 \%(3)$
\end{tabular}

How did you try to quit?

On my own

Sought treatment

Where did you receive treatment?

Primary care

$18.8 \%(3)$

Specialized services

$62.5 \%(10)$

Psychosocial Care Center

$25.0 \%(4)$

Note: * median, interquartile distance. ${ }^{* *}$ Not applicable or invalid answers were omitted from table.

For the purpose of this study, smokers were classified as light smokers (10 cigarettes per day), smokers (11-19 cigarettes per day), and heavy smokers (20 or more cigarettes per day) (Reichert et al., 2008). The number of each type of smoker for each type of disorder is shown in Figure 1. Note that the percentage of heavy smokers is higher among patients with mood disorders (7.4\%) and non-smokers constituted a smaller percentage of patients with SSDD (53.5\%) than for other disorders $(60.1 \%$ of those with mood disorders and $71 \%$ of those with NSSD were non-smokers). Of patients with NSSD, $4 \%$ were heavy smokers, while $4.7 \%$ of those with SSDD are in this category. The percentage of light smokers did not vary much among patients with SSDD, mood disorders, and NSSD (12.8\%, 14.1\%, and 14\% respectively). 


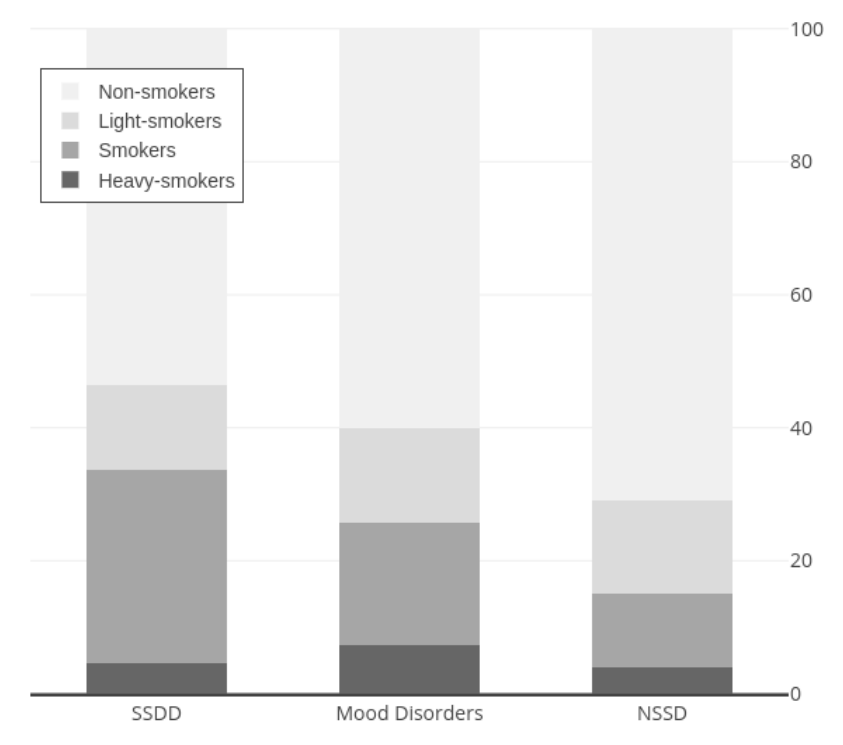

Figure 1. Percentage of heavy smokers, smokers, light smokers and non-smokers by type of disorder.

\section{Discussion and Conclusion}

The results of this study suggest that interventions to control tobacco use need to be integrated with the treatment for mental disorders, since this co-occurring disorder is highly prevalent. Smoking was found to be more prevalent among users of these healthcare services $(37.8 \%)$, when compared to the national prevalence for general population (14.7\%) (Monteiro, Cavalcante, Moura, Claro, \& Szwarcwald, 2007). The prevalence was similar to prevalence found in literature (Grant, Hasin, Chou, Stinson, \& Dawson, 2004). Furthermore, it was observed that the vast majority would like to quit smoking, but patients' attempts on quitting smoking on their own were not supported by any interventions as part of the treatments they were undergoing. This estimate is 
compatible with previous study on general population; $49 \%$ of smokers in Brazil plan to quit in 6 months (Projeto ITC et al., 2017).

One reason for the lack of anti-smoking interventions among the treatments offered to patients with mental illness is the theory of self-medication (Ziedonis et al., 2008). According to this, people with symptoms of depression or anxiety use tobacco believing that is therapeutic. This theory has been used by healthcare teams to justify their tolerance of tobacco use by patients with mental disorders, which potentially reinforces this habit (Barros et al., 2014). This situation is worsened by the fact that nicotine is administered through cigarettes, which is not appropriate for mental health patients (Ziedonis et al., 2008). Therefore, it is essential that health professionals be educated about smoking as a risk factor and disease so that anti-smoking strategies are incorporated into routine services.

With regard to diagnosis, although heavy smokers constitute a higher percentage of patients with mood disorders, smoking was found to be more prevalent among patients with SSDD (46.5\%). These results may indicate that tobacco is being used as a strategy to cope with the side effects of medication and/or the losses associated with this health condition. The literature also offers evidence of a link between schizophrenia and high nicotine dependence, with lower rates of quitting, compared to the general population (Rondina, Gorayeb, \& Botelho, 2003).

As for the relationship between the type of treatment and tobacco use, it is observed that patients who received daily treatment reported higher rates of tobacco use $(49.0 \%)$ than patients who had periodic appointments (33.5\%). Considering that patients in the first group receive daily care, we suggest that anti-smoking treatment should be incorporated into the daily treatment process (World Health Organization, 2019). Although treating patients with mental disorders presents challenges and these patients are less likely to quit smoking (Rondina et al., 2003), reduction and eventual 
quitting of tobacco consumption is a strategy that needs to be considered a part of these patients' treatment. The fact that these patients receive regular care means that it is feasible to approach them and treat them to quit smoking. However, since specialized services are available, such initiatives often go unnoticed. This raises the question of whether the healthcare network is too fragmented.

Paim (2008) indicates that the overlap between existing programs and projects for various risk groups will magnify the inefficiency and bureaucratization of the services. Moreover, there is enough evidence suggesting that treatment for mental disorders and quitting tobacco use are most effective when integrated (Scherer et al., 2012; Thornton et al., 2012).

In our sample, the smokers were predominantly men, which corroborates the results of the national research (Ministério da Saúde, 2015; Instituto Nacional do Câncer, 2011). Furthermore, PETab (Instituto Nacional do Câncer, 2011) showed that smoking usually begins before the 19 years of age. Our data are consistent with this research since $67.2 \%$ of the sample reported they had started smoking by that age. This result indicates the need to promote prevention strategies aimed at the youth.

The studies cited above also indicate that the percentage of smokers is inversely proportional to the years of education. In a national telephone survey in 2015 (Ministério da Saúde, 2015), the percentage of smokers who had 9-11 years of schooling was significantly lower (about 50\%) compared to those with $0-8$ years of schooling (1.8\% and $4.1 \%$, respectively). Most of the smokers in our sample had at most a secondary education level (68\%) and only $25.5 \%$ reported having graduated from high schools, while $37.8 \%$ of non-smokers said they had graduated from high school.

Manufactured cigarettes are the most frequent way in which tobacco is consumed, similar to Vigitel and National findings (Ministério da Saúde, 2015; Instituto Brasileiro 
de Geografia e Estatística [IBGE], 2014). This may be due to its accessibility, low cost, and availability through legal markets. Media influence may also contribute to cigarette smoking since tobacco use is heavily advertised to increase consumption (Instituto Nacional do Câncer, 2007). Although, the federal law in Brazil banned tobacco advertising and to be considered one of most advanced country in terms of tobacco control (World Health Organization, 2019), the industry still maintains effective advertising strategies in Brazil (Lobianco, 2018).

Other data obtained in the study highlights attempts to quit smoking. Of the $79.6 \%$ of respondents $(n=109)$ who claimed they had tried to quit smoking, 84.3\% $(n=91)$ undertook the effort on their own, while National findings (IBGE, 2014) suggests that $73.1 \%$ of those who quit smoking in 2013 received treatment from a health care professional. This might be because the patients did not know that they could receive help to quit smoking and because health professionals did not inquire about tobacco use while taking patients' medical histories. It is important that treatment for smoking should be included in routine care at health facilities, since this can be considered a chronic disease that is directly related to other health conditions (Instituto Nacional do Câncer, 2007). Similarly, the PETab (Instituto Nacional do Câncer, 2011) showed that approximately $40 \%$ of the health professionals carelessly overlook smoking as a risk factor and cause of diseases. Another challenge for developing countries is about health disparities. In Brazil, health disparities are linked to social determinants like social class, race, gender and territory (Travassos \& Castro, 2008). Although Brazil has a universal health system, social inequalities are still a barrier for access to effective care (Juarez et al., 2014).

This study highlights the prevalence of smoking among people being treated for mental disorders and emphasizes the importance of combating this problem, which is often overlooked in health services. These results lead us to reiterate the co-occurring 
disorder concept and the need for localized studies on tobacco use among patients being treated for mental disorders, a population rarely studied in Brazil and Latin America. The high rates of consumption revealed the importance of integrating antismoking treatment with treatment for mental disorders. Further studies are needed for a more detailed investigation into aspects related to tobacco consumption and personal strategies to quit smoking.

However, some limitations should be observed. First, it is not possible to generalize from this study since participants were not chosen at random, and the study was conducted in a medium-sized city. This limitation makes inferential analysis and statistical modeling difficult. Further, the sample consisted of people with only three types of disorders, not covering, for example, people with personality disorders. We chose these three categories because they were the most common disorders and allowed us to make comparisons.

This study creates awareness in health professionals about the importance of integrating the dual diagnosis, analysis and treatment of tobacco use into the daily routine of services, contributing to a better understanding of aspects related to a patient's health and treatment process. The fact that tobacco harms the patients' health and interferes with their treatment highlights the need for more studies in this area. These will lead to a better understanding of this phenomenon, the health conditions of this population, the improvement of anti-smoking interventions and strategies that will contribute to the treatment of mental disorders.

\section{Acknowledgements}

The authors wish to express their gratitude to the National Council for Scientific and Technological Development (CNPq), the Office of Professional Development for Higher 
Education Personnel (CAPES), and the Foundation for the Support of Research of Minas Gerais (FAPEMIG CBB APQ 03256/13) for their financial support of this project.

\section{References}

Barros, F.C.R., Melo, A.P.S., Cournos, F., Cherchiglia, M.L., Peixoto, E.R.M., \& Guimarães, M.D.C. (2014). Cigarette smoking among psychiatric patients in Brazil. Cadernos de Saúde Pública, 30(6), 1195-206.

Degenhardt, L., \& Hall, W. (2001). The association between psychosis and problematical drug use among Australian adults: findings from the National Survey of Mental Health and Well-Being. Psychological Medicine, 31(4), 65968.

Grant, B. F., Hasin, D. S., Chou, S. P., Stinson, F. S., \& Dawson, D. A. (2004). Nicotine Dependence and Psychiatric Disorders in the United States: Results From the National Epidemiologic Survey on Alcohol and Related Conditions. Archives of General Psychiatry, 61(11), 1107-1115.

Instituto Nacional de Câncer (2007). Tabagismo um grave problema de saúde pública. Rio de Janeiro: INCA.

Instituto Nacional do Câncer (2011). Pesquisa Especial de Tabagismo - PETab: relatório Brasil. Rio de Janeiro: INCA.

Instituto Brasileiro de Geografia e Estatística (IBGE) (2014). Pesquisa Nacional de Saúde 2013. Percepção do estado de saúde, estilo de vida e doenças crônicas. Rio de Janeiro: IBGE.

Johnson, J.L., Ratner, P.A., Malchy, L.A., Okoli, C.T.C., Procyshyn, R.M., Bottorff, J.L., Groening, M. ...Osborn, M. (2010). Gender-specific profiles of tobacco use among non-institutionalized people with serious mental illness. BMC Psychiatry, 10(1), 101. 
Juarez, P.D., Matthews-Juarez ,P., Hood, D.B., Im, W., Levine, R.S., Kilbourne, B.J., Langston, M.A., Al-Hamdan, M.Z. ...Lichtveld, M.Y. (2014). The Public Health Exposome: A Population-Based, Exposure Science Approach to Health Disparities Research. International Journal of Environment Research and Public Health, 11, 12866-12895.

Lobianco, C.L. (2018). A propaganda do cigarro: estratégias publicitárias pós condenação do tabagismo no Brasil (Dissertação de Mestrado). Centro de Pesquisa e Documentação de História Contemporânea do Brasil (CPDOC). Rio de Janeiro, RJ, Brasil.

Mackowick, K.M., Lynch, M.J., Weinberger, A.H., \& George, T.P. (2012). Treatment of Tobacco Dependence in People with Mental Health and Addictive Disorders. Current Psychiatry Reports, 14(5),478-85.

Ministério da Saúde (2015). Vigitel Brasil 2014: vigilância de fatores de risco e proteção para doenças crônicas por inquérito telefônico. Brasília: Ministério da Saúde.

Monteiro, C. A., Cavalcante, T. M., Moura, E. C., Claro, R. M., \& Szwarcwald, C. L. (2007). Population-based evidence of a strong decline in the prevalence of smokers in Brazil (1989-2003). Bulletin of the World Health Organization, 85(7), 527-534.

Paim, J. (2008). Modelos de atenção à saúde no Brasil. In: Giovanella, L., Escorel L., Lobato, L., Noronha, J., \& Carvalho, A. (Orgs). Políticas e Sistema de Saúde no Brasil. Rio de Janeiro: Fiocruz.

Projeto ITC, Universidade de Waterloo, Ministério da Saúde, Instituto Nacional de Câncer José Alenxar Gomes da Silva, Ministério da Justiça do Brasil, Fundação do Câncer, Aliança de Controle do Tabaco, \& Fundação Oswaldo 
Cruz. (2017). Relatório do projeto ITC Brasil. Resultados das Ondas 1 a 3 da Pesquisa (2009-2016/2017) (p. 56).

Reichert, J., Araújo, A.J., Gonçalves, C.M.C., Godoy, I., Chatkin, J.M., Sales, M.P.U., \& Santos, S.R.R.A. (2008). Diretrizes para cessação do tabagismo - 2008. Jornal Brasileiro Pneumologia, 34(10):845-80.

Rondina, R.D.C., Gorayeb, R., \& Botelho, C. (2003) Relação entre tabagismo e transtornos psiquiátricos. Revista de Psiquiatria Clínica, 30(6),221-8.

Scherer, E.A., Scherer, Z.A.P., Azevedo, H.A., \& Durão, A.M.S. (2012). Opinião de pacientes psiquiátricos internados sobre o hábito de fumar. SMAD, Revista Eletrônica Saúde Mental Álcool e Drogas, 8(1),25-33.

Teesson, M., Slade, T., \& Mills, K. (2009). Comorbidity in Australia: findings of the 2007 National Survey of Mental Health and Wellbeing. Australian \& New Zealand Journal of Psychiatry, 43(7),606-14.

Thornton, L.K., Baker, A.L., Johnson, M.P., \& Lewin, T. (2013). Perceived risk associated with tobacco, alcohol and cannabis use among people with and without psychotic disorders. Addictive Behavior, 38(6), 2246-51.

Thornton, L.K., Baker, A.L., Lewin, T.J., Kay-Lambkin, F.J., Kavanagh D, Richmond R, Kelly, B., \& Jhonson, M.B. (2012). Reasons for substance use among people with mental disorders. Addictive Behavaviors, 37(4), 427-34.

Travassos, C., Castro, M.S.M. (2008). Determinantes e Desigualdades Sociais no Acesso e na Utilização dos Serviços de Saúde. In Giovanella, L., Escorel L., Lobato, L., Noronha, J., \& Carvalho, A. (Orgs). Políticas e Sistema de Saúde no Brasil. Rio de Janeiro: Fiocruz.

World Health Organization (2011). WHO report on the global tobacco epidemic, 2011: warning about the dangers of tobacco. Geneve: OMS. 
World Health Organization (2019). WHO report on the global tobacco epidemic, 2019: Offer help to quit tobacco use. Geneve: OMS.

Ziedonis, D., Hitsman, B., Beckham, J.C., Zvolensky, M., Adler LE, Audrain-McGovern, J., Breslau, N., ... Riley, W.T. (2008). Tobacco use and cessation in psychiatric disorders: National Institute of Mental Health report. Nicotine \& Tobacco Research, 10(12),1691-715.

\section{Authors' contribution statement}

TMR contributed to the design, implementation and analysis of the research, BABBA to the data collection and implementation, HPG and FABC to the analysis of the results and the writing of the manuscript with the support of all authors. All authors discussed the results and contributed to the final manuscript.

\section{Editor se sección}

La editora de sección de este artículo fue Pilar Bacci.

ORCID ID: 0000-0002-6611-1905

\section{Formato de citación}

Mota, T., Bianchi, B., Pinto, H. \& Basile, F. (2020). Prevalence and Treatment of Tobacco Use Among Patients Being Treated for Mental Disorders. Psicología, Conocimiento $y \quad$ Sociedad, 10(2), 101-122. doi: http://dx.doi.org/10.26864/PCS.v10.n2.5 